\title{
Impact of Traffic Flows and Meteorological Events on the Hourly Elemental Composition of Fine and Coarse Particles at an Urban Site
}

\author{
Jose Nicolás $^{1^{*}}$, Franco Lucarelli ${ }^{2}$, Nuria Galindo ${ }^{1}$, Eduardo Yubero ${ }^{1}$, Javier Crespo ${ }^{1}$, \\ Giulia Calzolai ${ }^{2}$, Silvia Nava ${ }^{2}$ \\ ${ }^{1}$ Atmospheric Pollution Laboratory (LCA), Department of Applied Physics, Miguel Hernández University, Avenida de la \\ Universidad S/N, 03202 Elche, Spain \\ ${ }^{2}$ Department of Physics and Astronomy, University of Florence and INFN, Sesto Fiorentino, Italy
}

\begin{abstract}
Hourly $\mathrm{PM}_{2.5}$ and $\mathrm{PM}_{2.5-10}$ samples were collected with a Streaker sampler over one week at an urban site located on the Spanish Mediterranean coast. The samples were subsequently analysed using the PIXE technique to determine their elemental composition. Despite the influence of traffic at the site, the atmospheric concentrations of the traffic-related components fell within the lower range of values reported for urban stations with similar characteristics. The concentrations of the elemental tracers for non-exhaust emissions $(\mathrm{Cu}, \mathrm{Zn}, \mathrm{Mn}, \mathrm{Al}, \mathrm{Ca}$ and $\mathrm{Fe})$ in the $\mathrm{PM}_{2.5-10}$ fraction displayed the strongest correlations with the traffic density $\left(\mathrm{R}^{2}>0.5\right)$, with lower correlation coefficients calculated for the fine fraction. A short Saharan dust episode identified during the study period increased the concentrations of the crustal elements $(\mathrm{Al}, \mathrm{Ca}, \mathrm{K}$, Ti, $\mathrm{Sr}$ and $\mathrm{Fe}$ ), mainly in the coarse fraction. Nevertheless, the concentrations of the sea-spray elements exhibited higher relative increases, indicating that the Saharan dust plume reached the sampling site following a marine path. The high temporal resolution of the PM sampling allowed us to identify the effects of a brief but intense precipitation event, during which a higher atmospheric removal efficiency, peaking at the rate of $17 \mathrm{~L} \mathrm{~m}^{-2}$ in one hour, was observed for coarse particles than fine particles. As a result of this precipitation, most of the measured elemental concentrations in the $\mathrm{PM}_{2.5-10}$ fraction decreased below detection limits.
\end{abstract}

Keywords: Streaker; PIXE; Traffic; Saharan dust; Precipitation.

\section{INTRODUCTION}

In urban environments with no industrial activity, road traffic is the main emission source of atmospheric particulate matter (PM). Vehicle emissions can be divided into exhaust and non-exhaust emissions. Direct (abrasion) and indirect (resuspension) emissions are included in the non-exhaust component (Pant and Harrison, 2013). Several previous studies (Thorpe and Harrison, 2008; Lawrence et al., 2013; Pant and Harrison, 2013; Alves et al., 2018) have identified and compiled the main elements associated with both processes. Specific elements are frequently associated with nonexhaust traffic-induced emissions. $\mathrm{Cu}, \mathrm{Fe}, \mathrm{Zn}, \mathrm{Mn}, \mathrm{Sb}, \mathrm{Ba}$ and $\mathrm{Sn}$ are present in brake dust, $\mathrm{Zn}$ is considered as the key tracer of tyre wear, and crustal elements such as Al, Ca, Fe or $\mathrm{Si}$ are closely related to vehicle-induced resuspension.

\footnotetext{
${ }^{*}$ Corresponding author.

Tel.: +34 966658325

E-mail address: j.nicolas@umh.es
}

With regard to exhaust emissions, elemental markers such as $\mathrm{Cu}, \mathrm{Mn}, \mathrm{Fe}, \mathrm{Zn}, \mathrm{Ba}, \mathrm{Sn}, \mathrm{Mo}$ and $\mathrm{Sb}$ have been identified in previous studies. These elements can be emitted from different processes including fuel and lubricant combustion, catalytic converters, particulate filters and engine corrosion (Pant and Harrison, 2013).

Depending on the emitting process, these elements can be found either in the fine or the coarse mode. PM components emitted from combustion processes are mainly found in the fine fraction $\left(\mathrm{PM}_{2.5}\right)$, while elements derived from nonexhaust emissions are primarily associated with the coarse fraction $\left(\mathrm{PM}_{2.5-10}\right)$ (Handler et al., 2008; Pant and Harrison, 2013). In spite of this, the relationship of these elements with PM sources and particle size is not necessarily unequivocal, as shown in several studies (Moreno et al., 2013; Crilley et $a l ., 2016)$. These works established the chemical profile of the main PM sources in urban environments using hourly data, which implies a substantial improvement in the identification of atmospheric aerosol sources (Crilley et al., 2016).

High-time resolution measurements can provide a more comprehensive view of the influence of specific atmospheric processes on the variability of PM components. 
Meteorological events such as rainfall, transport of mineral dust from arid areas or substantial variations in the mixing layer height can affect the size and composition of atmospheric particles. The influence of these events and the contribution of PM emissions from different sources, especially traffic-related sources, determine the temporal variability of PM concentrations in urban environments.

Rainfall and the transport of mineral dust from arid areas are two of the most important meteorological events, each having an opposite effect on PM concentrations. Precipitation scavenging is the most important sink of aerosols in the troposphere (Loosmore and Cederwall, 2004). Although the duration and intensity of precipitation events are key factors in the removal efficiency of atmospheric aerosols, different studies pointed out that coarse particles are removed more efficiently than fine particles (Andronache, 2003; Nicolás et al., 2009a; Amato et al., 2012; Feng and Wang, 2012). Rainfall episodes also reduce road dust resuspension. Nevertheless, it is difficult to establish a correlation between the duration of the precipitation event and the time needed to reach PM concentrations previous to the episode. In general, road dust emissions recover faster after daytime precipitation because primary (traffic) emissions are still occurring and solar radiation accelerates the mobilization of particles by water evaporation (Amato et al., 2012).

In the western Mediterranean Basin, Saharan dust events (SDE) can significantly contribute to PM concentrations in urban environments. Although increases in PM concentrations have been recorded for all particle sizes, the coarse fraction is more affected by these events than the fine fraction (Contini et al., 2014; Nicolás et al., 2014). Thus, SDE are the main cause of the exceedances of the $\mathrm{PM}_{10}$ daily limit value established by the European legislation (Escudero et al., 2007; Nava et al., 2012; Cuspilici et al., 2017). During SDE the concentrations of crustal components such as $\mathrm{Ti}$ and $\mathrm{Fe}$ show significant increments; however, increases in the levels of non-crustal elements like $\mathrm{Ni}$ or $\mathrm{V}$, mainly related to combustion processes, have also been observed. This is probably due to the transport of anthropogenic pollutants by Saharan dust plumes (Nicolás et al., 2011; Malaguti et al., 2015; Galindo et al., 2018). Likewise, SDE may produce an increase in the concentrations of marine elements $(\mathrm{Na}, \mathrm{Cl}$ and $\mathrm{Mg}$ ) as a result of the uptake of these species during the transport of Saharan air masses over the Mediterranean Sea.

The purpose of this study is to determine the influence of traffic flows and some meteorological events (SDE and a short but intense rain period) on the elemental composition of $\mathrm{PM}_{2.5}$ and $\mathrm{PM}_{2.5-10}$ samples collected with a high time resolution (1 hour). The high temporal resolution of measurements will provide insights into the sensitivity of the analysed components to daily traffic cycles and different meteorological episodes. The results of this study can provide a scientific basis for improving urban air quality.

\section{EXPERIMENTAL}

\section{Sampling Site}

The sampling site was placed in the urban centre of Elche $\left(38^{\circ} 16^{\prime} ; 0^{\circ} 41^{\prime} ; 86 \mathrm{~m}\right.$ a.s.1.). The city is located in the southeast of Spain, only $12 \mathrm{~km}$ from the Mediterranean coast. Elche is the third biggest city in the Valencian Community, with a population of about 192,000 inhabitants (data from 2016). The urban area is located on a plain and crossed by the Vinalopó River. Elche is also known by its high density of palm tree gardens and for being one of the largest shoe manufacturing centres in Europe. However, it should be noted that no large industries are present in the city, so the main PM source in the urban area is road traffic (Yubero et al., 2015).

The climate in Elche is considered as arid Mediterranean. In fact, rainfall is quite scarce, with annual values not exceeding $300 \mathrm{~L} \mathrm{~m}^{-2}$. Precipitation episodes usually concentrate during the fall and spring months. Breeze regimes (E-SE) are very frequent during the summer months, while during winter the wind usually blows from the northwest. The average temperature in the city ranges from about $27^{\circ} \mathrm{C}$ (August) to $12^{\circ} \mathrm{C}$ (January). During November, when this study was carried out, the average temperature is usually around $16^{\circ} \mathrm{C}$.

The measurement site was situated $\sim 3-4 \mathrm{~m}$ above ground level, on a narrow street of about $7 \mathrm{~m}$ width. The street has two traffic lanes and is surrounded by buildings of approximately $25 \mathrm{~m}$ height. The average density of vehicles on working days varies between 8000 and 9000 vehicles day ${ }^{-1}$ (data from the Elche traffic office). The sampling point can be considered as representative of an urban environment heavily influenced by traffic. In Galindo et al. (2018), graphic documentation related to the location of the sampling site can be found. Previous studies on the temporal variability of $\mathrm{PM}_{10}$ and $\mathrm{PM}_{1}$ concentration and composition in this area can be found in Yubero et al. (2015), Galindo and Yubero (2017) and Galindo et al. (2018).

\section{Instrumentation and Data Analysis}

Fine and Coarse Particle Elemental Composition: Streaker and PIXE

The aerosol was collected during one week, from $15^{\text {th }}$ to $21^{\text {st }}$ November 2011, by a Streaker sampler (PIXE International Corporation, http://pixeintl.com/Streaker.asp). This device is designed to separate the fine $(<2.5 \mu \mathrm{m}$ aerodynamic diameter) and the coarse $(2.5-10 \mu \mathrm{m})$ modes of the aerosol. A paraffin-coated Kapton foil is used as an impaction surface for coarse particles and a Nuclepore membrane as a fine particle collector. The two collecting plates are paired on a cartridge that rotates at a constant speed for a week. This produces a circular continuous deposition of particulate matter at both stages. The rotation speed during sampling $\left(1.2 \mathrm{~mm} \mathrm{~h}^{-1}\right)$, the pumping orifice width $(1.2 \mathrm{~mm})$ and the beam size normally used for the subsequent particle-induced $\mathrm{X}$-ray emission (PIXE) analysis are such that an overall resolution of about one hour is obtained on the elemental composition of air particulate matter (Chiari et al., 2006; Calzolai et al., 2015). PIXE analyses were performed with 3 $\mathrm{MeV}$ protons from the $3 \mathrm{MV}$ Tandetron accelerator of the LABEC laboratory of INFN in Florence, with the external beam set-up extensively described elsewhere (Calzolai et al., 2010; Lucarelli et al., 2014; Lucarelli et al., 2018). The beam scanned the streak in steps corresponding to one hour of aerosol sampling. Each spot was irradiated for about $60 \mathrm{~s}$ with a beam intensity ranging from $20 \mathrm{nA}$ to $300 \mathrm{nA}$. PIXE 
spectra were fitted using the GUPIX software package (Campbell et al., 2010) and elemental concentrations (Na, $\mathrm{Mg}, \mathrm{Al}, \mathrm{Si}, \mathrm{P}, \mathrm{S}, \mathrm{Cl}, \mathrm{K}, \mathrm{Ca}, \mathrm{Ti}, \mathrm{V}, \mathrm{Cr}, \mathrm{Mn}, \mathrm{Fe}, \mathrm{Ni}, \mathrm{Cu}, \mathrm{Zn}$, $\mathrm{As}, \mathrm{Se}, \mathrm{Br}, \mathrm{Rb}, \mathrm{Sr}, \mathrm{Zr}$, Mo and $\mathrm{Pb}$ ) were obtained via a calibration curve from a set of thin standards of known surface density. Concentration uncertainties were determined by a sum of independent uncertainties on standard thicknesses (5\%), X-ray counting statistics (from $2 \%$ to $20 \%$ or higher when concentrations approach method detection limits (MDLs)) and sampling parameters $(10 \%)$. Field blank corrections were applied to all the data sets. The accuracy of analysis was checked against certified reference materials (NIST SRM 2783). The total number of hourly samples collected during the sampling period was 156 .

Detection limits were about $10-20 \mathrm{ng} \mathrm{m}^{-3}$ for elements from $\mathrm{Na}$ to $\mathrm{Ca}$, and $5 \mathrm{ng} \mathrm{m}^{-3}$ (or below) for elements from Ti to $\mathrm{Pb}$. The percentage of valid samples in both fractions was higher than $70 \%$ for most of the elements ( $\mathrm{Na}, \mathrm{Mg}, \mathrm{Al}$, $\mathrm{S}, \mathrm{Cl}, \mathrm{K}, \mathrm{Ca}, \mathrm{Cr}, \mathrm{Fe}, \mathrm{Ni}, \mathrm{Cu}$ and $\mathrm{Zn}$ ). $\mathrm{Br}$ and $\mathrm{Si}$ in the fine fraction could not be quantified in this study due to the high background levels in the substrate.

\section{Meteorology and Traffic Density}

It should be indicated that all hours in this study are in local time (UTC+1), unless otherwise stated. Hourly values of the main meteorological variables were obtained from a station of the Environmental Monitoring Network of the Valencian Community located on the outskirts of the city. The Global Data Assimilation System (GDAS1) model from the NOAA Air Resources Laboratory (http://www.ready.noaa. gov/READYamet.php) was used for the determination of the planetary boundary layer (PBL) height. Saharan dust events were identified using back-trajectory analysis supported by the outcomes of the BSC-DREAM model. During the study period, a low-intensity SDE was detected between Sunday $20^{\text {th }}$ at 07:00 and Monday $21^{\text {st }}$ at 11:00. The event finished due to a precipitation episode, occurring on Monday $21^{\text {st }}$ between 05:00 and 13:00. The accumulated precipitation during the event was $28 \mathrm{~L} \mathrm{~m}^{-2}$, peaking at $17 \mathrm{~L} \mathrm{~m}^{-2}$ between 07:00 and 08:00 (Fig. 1(a)). Throughout this time period, rainfall was heavy. Figs. 1(b) and 1(c) show the hourly evolution of wind speed and direction, PBL height and relative humidity. The impact of the PBL height on PM concentrations was established from particle number concentration $(\mathrm{N})$ measurements obtained with a Grimm 365 optical spectrometer located on the roof of a university building. The instrument is able to determine particle number concentrations in 31 particle size channels from $0.25 \mu \mathrm{m}$ to $32 \mu \mathrm{m}$. Fine particle concentrations have been obtained as a result of the $\mathrm{N}$ addition from $0.25 \mu \mathrm{m}$ to $1 \mu \mathrm{m}$. Likewise, coarse particles concentrations is the result of the $\mathrm{N}$ addition from $1 \mu \mathrm{m}$ to $32 \mu \mathrm{m}$. The site was $15 \mathrm{~m}$ above the ground and approximately $1.5 \mathrm{~km}$ northeast of the measurement site.

Fig. 1(d) shows the temporal evolution of fine and coarse number concentrations. As can be seen, the SDE had a greater impact on coarse particles, with a peak value of $\sim 0.5 \mathrm{~cm}^{-3}$ at the end of the event. The Saharan outbreak was followed by a precipitation event which caused wet scavenging of atmospheric particles. The figure also shows an increase in particle number concentration during the breeze period and a rise in the concentration of submicrometric particles (the increase for particles larger than $1 \mu \mathrm{m}$ was lower) when the PBL height was lowest. Fig. S1 included in the supplementary material shows the impact of the SDE on the study area at 12:00 UTC on $20^{\text {th }}$ November along with the precipitation episode that occurred the following day.

Traffic density (TD) at the sampling point was obtained from the Elche traffic office. The hourly evolution of the number of vehicles during the sampling period is shown in Fig. 2. Conclusions that can be drawn from the information presented in this figure are: a) the average number of vehicles during working days (8917) was clearly higher than that registered on Saturday (7636) and Sunday (6057); b) traffic densities on Saturday and Sunday significantly decreased between 14:00 and 16:00, while on working days they remained high; c) during both working days and weekends two maxima were observed (around 13:00 and 20:00); however, on weekdays the curve showed a third peak at the start of the working day (around 08:00-09:00). In addition, TD registered between 00:00 and 06:00 during the weekend was higher than that on working days. This can be seen in Fig. 2, where the percentage differences between TD on working days (WD) and Saturday (ST) are presented. The same pattern is generally observed throughout the year in the study area.

From now on only Saturday $19^{\text {th }}$ will be considered as weekend day in the analysis of the influence of traffic flows on PM composition. Sunday $20^{\text {th }}$ and Monday $21^{\text {st }}$ will not be considered in this analysis because they were affected by ana SDE and a precipitation episode that occurred afterwards.

\section{RESULTS}

\section{Average Elemental Concentrations}

Average elemental concentrations and standard deviations (SDs) for the coarse $\left(\mathrm{PM}_{2.5-10}\right)$ and fine $\left(\mathrm{PM}_{2.5}\right)$ fractions during the study period are shown in Table 1. Maximum and minimum hourly values are also presented. Concentrations of elements with percentages of valid samples below $20 \%$ are not included in this table.

Typical marine elements like $\mathrm{Na}$ and $\mathrm{Cl}$ showed high concentrations in the coarse fraction $(\mathrm{C})$ due to the close proximity of the sampling site to the Mediterranean coast. Levels of crustal elements such as $\mathrm{Si}, \mathrm{Ca}$ and $\mathrm{Fe}$ in the coarse size range were also significant. The mean $\mathrm{Mg} / \mathrm{Na}$ ratio obtained for the whole study period (0.12) is typical of bulk sea-water (Bardouki et al., 2003). However, the $\mathrm{Cl} / \mathrm{Na}$ ratio $(\sim 1.13)$ indicates a deficit of $\mathrm{Cl}$ due to the reaction of $\mathrm{NaCl}$ with sulphuric and nitric acids. In the fine fraction $(\mathrm{F}), \mathrm{S}$ was found to be the most abundant element, followed by $\mathrm{Na}$ and $\mathrm{Ca}$. There was no correlation between $\mathrm{Na}$ and $\mathrm{Cl}$ in this fraction because most of the $\mathrm{Cl}$ is missing due to the aforementioned reaction of $\mathrm{NaCl}$ with sulphuric and nitric acids, which is more effective in the fine fraction due to the more favourable surface to volume ratio (Yao et al., 2003).

Regarding mass size distributions, marine and crustal elements such as $\mathrm{Na}, \mathrm{Mg}, \mathrm{Cl}, \mathrm{Al}, \mathrm{Ca}$ and $\mathrm{Fe}$ were found mainly in the coarse fraction. $\mathrm{Ni}$ and especially $\mathrm{S}$ were 
a)

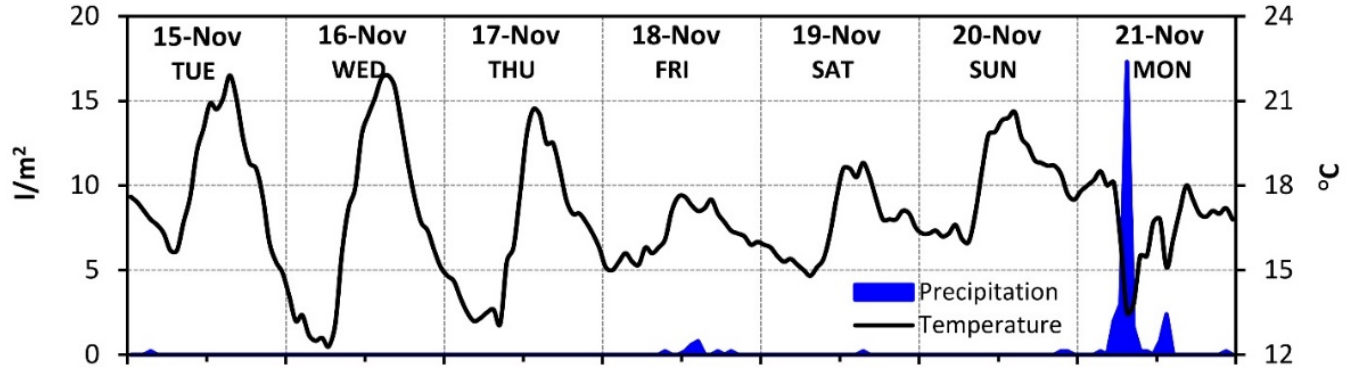

b)

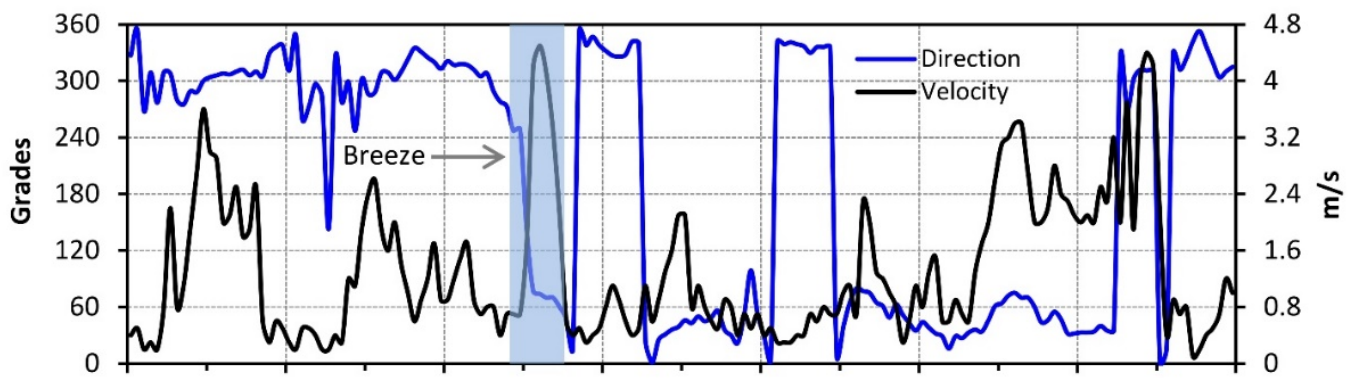

c)

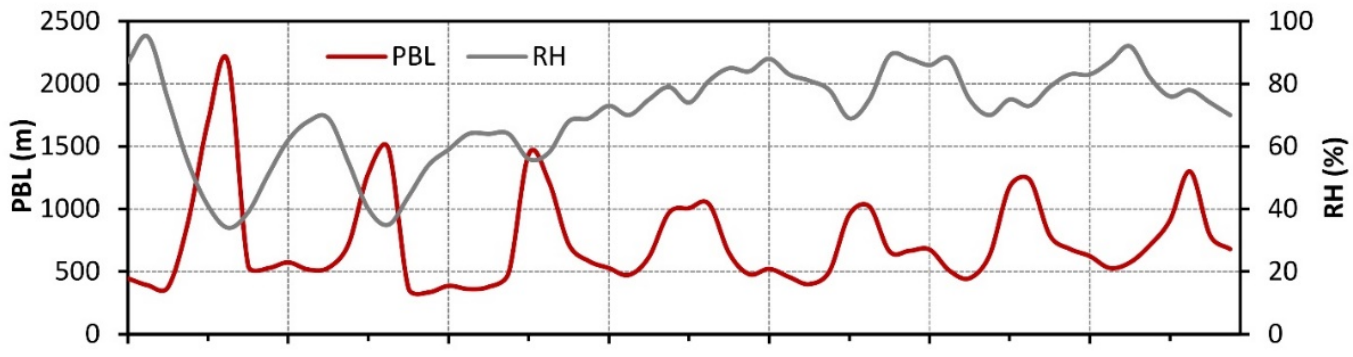

d)

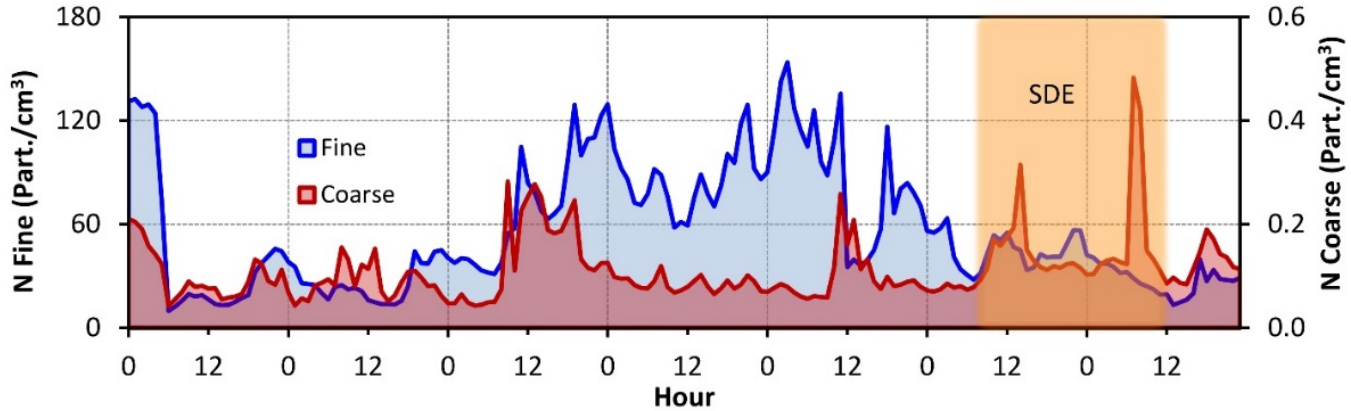

Fig. 1. Hourly time series of a) temperature and precipitation, b) wind direction and velocity, c) PBL height and relative humidity and d) coarse and fine particle concentrations. The Saharan dust event occurred at the end of the sampling is also shown.

distributed primarily in the fine fraction, while elements like $\mathrm{K}, \mathrm{Ti}, \mathrm{Cr}, \mathrm{Mn}, \mathrm{Cu}$ and $\mathrm{Zn}$ were almost evenly distributed between the two fractions.

It is difficult to compare elemental concentrations obtained in Elche with those measured at other urban locations due to multiple factors: different measurement periods, soil composition, distance to the sea and vehicle density. Even so, with the exception of marine elements $(\mathrm{Na}, \mathrm{Mg}$ and $\mathrm{Cl}$ ), concentrations obtained in this study were in the lower range of the values reported for other urban stations located in the western Mediterranean like, Barcelona (Dall'Osto et al., 2013; Minguillon et al., 2014), Florence (Lucarelli et al., 2000) or Palma de Mallorca (insular suburban site) (Pey et $a l ., 2009)$. It is noteworthy that $\mathrm{Zn}$ concentrations in both fractions were significantly lower than those previously measured at other Mediterranean urban areas.

As can be observed in Table 1, maximum hourly concentrations for some elements like $\mathrm{Na}, \mathrm{Cl}$ or $\mathrm{Fe}$, were considerably higher than the average values, particularly in the coarse fraction. This indicates that these elements are very sensitive to short-term episodes.

\section{The Influence of Traffic on Daily Patterns of Elemental Concentrations}

The relationship between daily patterns of TD on WD and ST (Fig. 2), and daily patterns of elemental concentrations in both mass fractions is discussed in this section. The hourly evolution of elemental concentrations on WD and ST is 


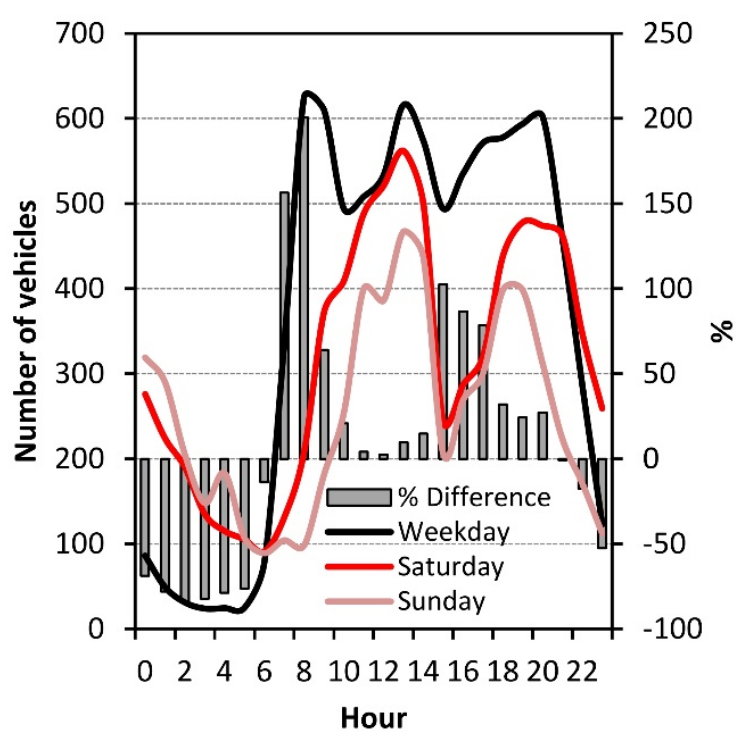

Fig. 2. Daily evolution of the number of vehicles at the sampling site on Saturday $20^{\text {th }}$, Sunday $21^{\text {st }}$ and on working days (from Tuesday $15^{\text {th }}$ to Friday $18^{\text {th }}$ ). The percentage difference between the number of vehicles on Saturday and on working days is also presented.

presented in Fig. S2. From the daily cycles shown in this figure, it can be inferred which elements are related to traffic emissions and which elements have a more regional origin.

Fig. 3(a) shows the determination coefficients $\left(\mathrm{R}^{2}\right)$ obtained by correlating elemental hourly concentrations (in the coarse fraction) with TD both on WD and ST. For many elements, the coefficients calculated for WD were higher than those obtained on ST. Some elements typically related to traffic, such as $\mathrm{Cu}, \mathrm{Fe}$ and $\mathrm{Mn}$, showed the highest coefficients $(>0.8$ on WD). Other elements associated with vehicle emissions $(\mathrm{Cr}$ and $\mathrm{Zn})$ or traffic resuspension $(\mathrm{Ti}, \mathrm{Ca}, \mathrm{Al}$ and $\mathrm{Si}$ ) showed moderately high determination coefficients. Although $\mathrm{S}$ had a moderate correlation with $\mathrm{TD}$, it is well known that traffic is not a major source of sulphur-containing compounds. The hourly evolution of $\mathrm{S}$ concentrations in the coarse fraction on WD (Fig. S2) showed a broad peak during the hours of higher solar radiation. A similar pattern was observed for $\mathrm{Na}$ and $\mathrm{Mg}$ and, to a lesser extent, $\mathrm{Ca}$. This points to the presence of secondary $\mathrm{Na}_{2} \mathrm{SO}_{4}$ and/or $\mathrm{CaSO}_{4}$ in the coarse fraction. The increase in $\mathrm{S}$ concentrations at midday was lower in $\mathrm{PM}_{2.5}$ than in the coarse fraction and is most likely associated with the photochemical formation of sulphate. The low correlations shown in Fig. 3(a) for $\mathrm{Na}$ and $\mathrm{Cl}\left(\mathrm{R}^{2}<\right.$ 0.3 ) can be explained considering that traffic is not the main source of coarse $\mathrm{Na}$ and $\mathrm{Cl}$ at our sampling site. Elements such as $\mathrm{Ni}$ and $\mathrm{P}$ did not show a correlation with traffic flows. For the remaining elements, correlations on WD were statistically significant ( $\mathrm{p}$-value $<0.05$ ). Correlations calculated on ST were also statistically significant for most of the analysed elements.

The determination coefficients calculated for the fine fraction (not shown) were significantly lower. Significant correlations $(>0.5)$ on WD were only obtained for $\mathrm{S}, \mathrm{Ca}, \mathrm{Fe}$ and $\mathrm{Zn}$. This points to a greater impact of vehicle emissions on the detected elemental concentrations in the coarse fraction than in the fine fraction in the study area (Galindo et al., 2018).

The percentage differences between elemental concentrations on WD and ST for both mass fractions are presented in Figs. 3(b) and 3(c). Since the percentage differences between the number of vehicles on WD and ST were highest at around 03:00 (-83\%), 08:00 (+200\%) and 15:00 (+103\%) (Fig. 2), Figs. 3(b) and 3(c) only show the differences at these hours and for the whole period. Most of

Table 1. Average elemental concentrations in $\mathrm{ng} \mathrm{m}^{-3}$ for the coarse and fine fractions. Maximum and minimum hourly levels are also shown.

\begin{tabular}{|c|c|c|c|c|c|c|}
\hline \multirow{2}{*}{ Element } & \multicolumn{3}{|c|}{$\mathrm{PM}_{2.5}$} & \multicolumn{3}{|c|}{$\mathrm{PM}_{2.5-10}$} \\
\hline & Mean (SD) & Max & Min & Mean (SD) & Max & Min \\
\hline $\mathrm{Na}$ & $233.9(118.1)$ & 671.3 & 51.0 & $922.9(798.9)$ & 3854.1 & 31.6 \\
\hline $\mathrm{Mg}$ & $42.1(15.1)$ & 80.4 & 23.2 & $114.1(78.9)$ & 369.8 & 17.3 \\
\hline $\mathrm{Al}$ & $41.5(29.9)$ & 142.1 & 0.5 & $62.0(53.0)$ & 299.8 & 9.3 \\
\hline $\mathrm{Si}$ & - & - & - & $269.0(137.0)$ & 885.0 & 84.3 \\
\hline $\mathrm{P}$ & - & - & - & $20.2(4.9)$ & 38.4 & 8.2 \\
\hline S & $294.3(140.6)$ & 555.2 & 16.6 & $97.4(60.8)$ & 287.6 & 23.2 \\
\hline $\mathrm{Cl}$ & $37.0(12.8)$ & 105.4 & 19.1 & $792.2(901.5)$ & 4624.2 & 10.0 \\
\hline K & $92.5(46.6)$ & 346.7 & 19.3 & $69.1(44.3)$ & 206.9 & 16.4 \\
\hline $\mathrm{Ca}$ & $159.1(75.1)$ & 390.3 & 25.5 & $581.2(317.3)$ & 1544.2 & 28.4 \\
\hline $\mathrm{Ti}$ & $7.9(2.7)$ & 17.7 & 4.7 & $9.0(5.0)$ & 23.6 & 2.1 \\
\hline V & $4.8(1.5)$ & 8.6 & 3.0 & - & - & - \\
\hline $\mathrm{Cr}$ & $5.0(1.6)$ & 11.6 & 1.9 & $3.3(2.9)$ & 34.7 & 1.1 \\
\hline $\mathrm{Mn}$ & $2.1(0.5)$ & 3.8 & 1.4 & $2.4(1.4)$ & 11.8 & 0.7 \\
\hline $\mathrm{Fe}$ & $83.6(26.7)$ & 141.5 & 26.2 & $203.4(144.5)$ & 1020.0 & 1.9 \\
\hline $\mathrm{Ni}$ & $1.9(0.6)$ & 3.8 & 0.9 & $1.2(3.9)$ & 46.4 & 0.3 \\
\hline $\mathrm{Cu}$ & $7.9(19.7)$ & 178.6 & 1.3 & $7.5(5.0)$ & 26.3 & 0.3 \\
\hline $\mathrm{Zn}$ & $6.1(2.4)$ & 13.1 & 1.3 & $4.9(2.8)$ & 14.7 & 0.4 \\
\hline $\mathrm{Br}$ & - & - & - & $1.2(0.8)$ & 4.2 & 0.3 \\
\hline $\mathrm{Sr}$ & - & - & - & $2.4(1.2)$ & 7.6 & 0.9 \\
\hline
\end{tabular}


a)

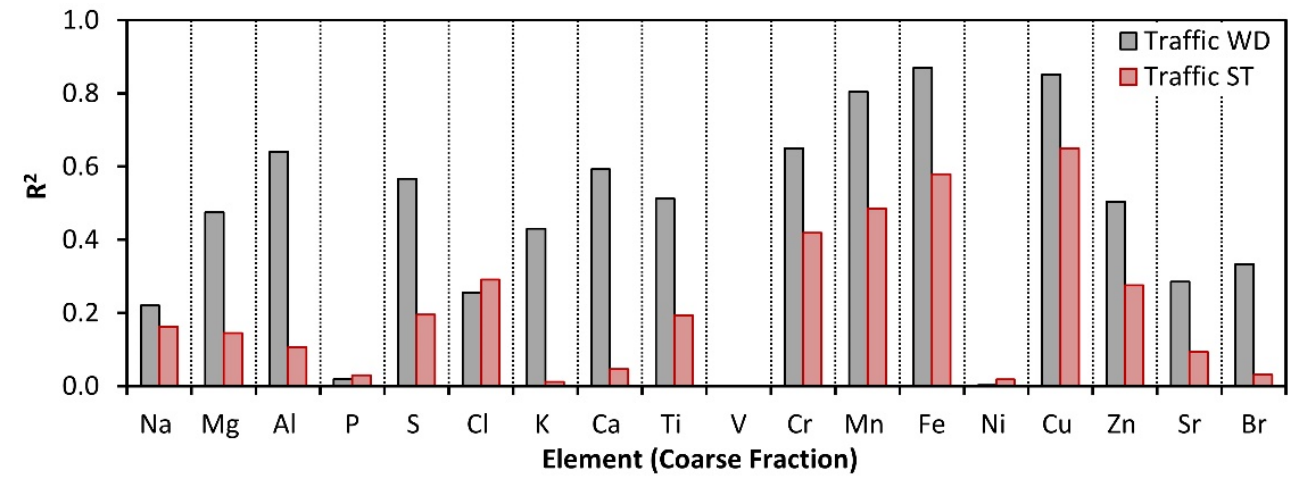

b)

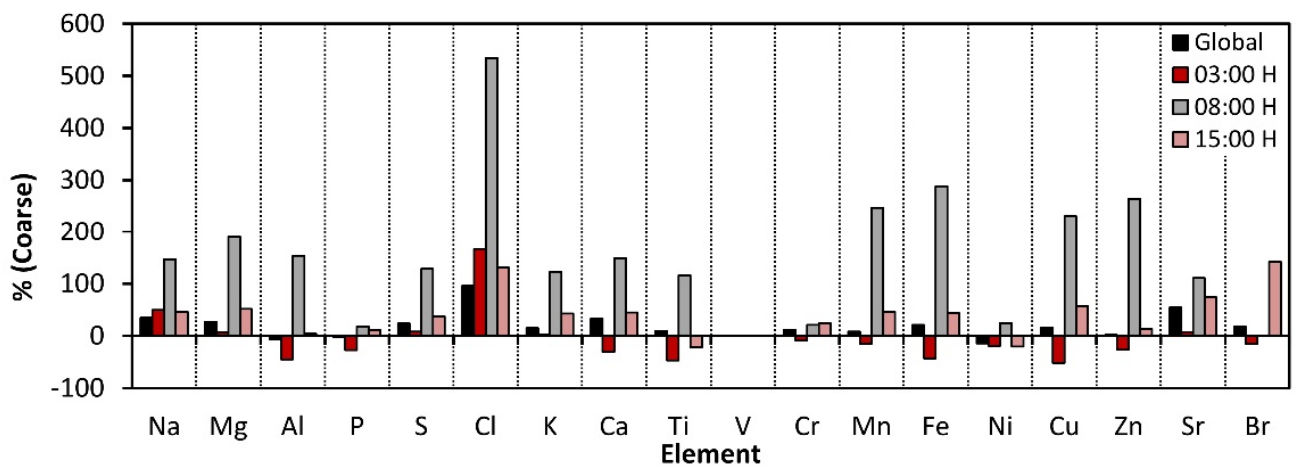

c)

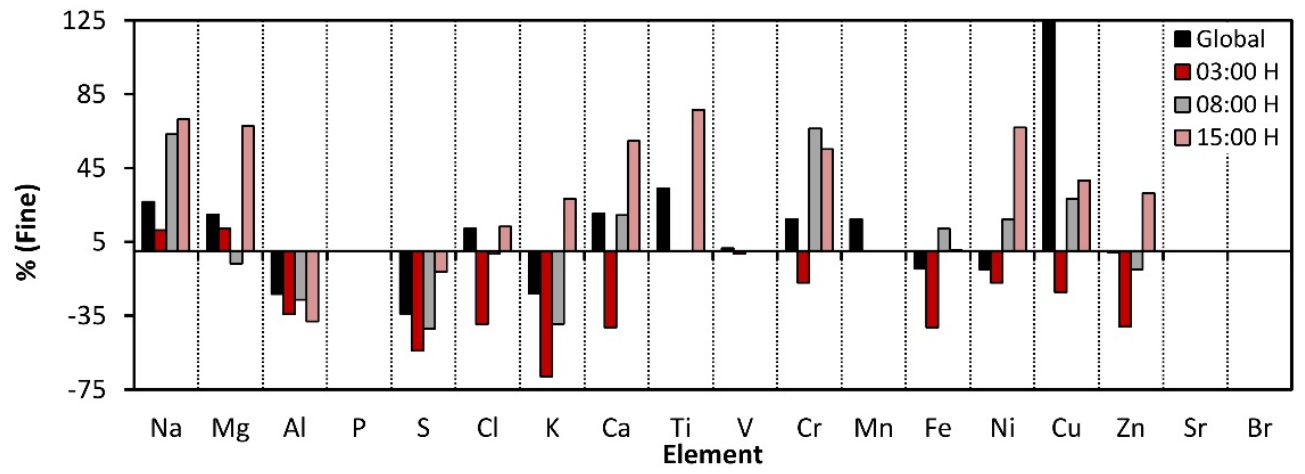

Fig. 3. (a) Values of the coefficient of determination $\left(\mathrm{R}^{2}\right)$ obtained in the regression analysis between the daily evolution of elements in coarse fraction and the number of vehicles during the weekday and Saturday; (b) percentage difference in concentration between weekdays and Saturday obtained for each element in the coarse fraction; (c) percentage difference in concentration between weekdays and Saturday obtained for each element in the fine fraction.

the elements in the coarse fraction (Fig. 3(b)) showed positive percentages for the whole period, meaning that concentrations during WD were higher than those registered on ST. The same was observed at 08:00 and 15:00. Nevertheless, elements typically associated with vehicle emissions $(\mathrm{Cu}$ and $\mathrm{Zn}$ ) or traffic-induced resuspension ( $\mathrm{Fe}, \mathrm{Ca}$, Ti and $\mathrm{Al}$ ) showed negative percentage differences at 03:00 due to a reduction in the number of vehicles on weekdays relative to the Saturday (Fig. 2). In the fine fraction (Fig. 3(c)), trafficrelated elements $(\mathrm{Zn}, \mathrm{Fe}, \mathrm{Cr}$ and $\mathrm{Cu})$, as well as $\mathrm{Cl}$ and $\mathrm{Ca}$, also showed negative percentage differences at 03:00.

\section{Meteorological Factors Affecting the Daily Evolution of Elements}

The temporal evolution of elemental concentrations throughout the study period is plotted in Fig. 4. As can be observed, some elements did not show a well-defined daily pattern. Different factors may affect the daily profiles of the analysed elements. The influence of traffic, one of the main factors affecting PM levels and composition in urban environments, has been discussed in the previous section. Different meteorological scenarios that can also have a significant influence on the observed variability will be examined in the next sections.

\section{Breeze}

It is worth noting the significant increase in the concentrations of $\mathrm{Na}(\mathrm{C}), \mathrm{Na}(\mathrm{F}), \mathrm{Cl}(\mathrm{C}), \mathrm{Mg}(\mathrm{C}), \mathrm{K}(\mathrm{C}), \mathrm{K}(\mathrm{F})$, $\mathrm{S}(\mathrm{C})$ and $\mathrm{S}(\mathrm{F})$ on Thursday $17^{\text {th }}$ during the central hours of the day. This was due to the intense sea breeze circulation (Fig. 1). The concentrations of these elements in the coarse fraction were increased by a factor from 5 to 12, suggesting a strong impact of the sea breeze on the temporal evolution of these components. Conversely, the increase in the levels 

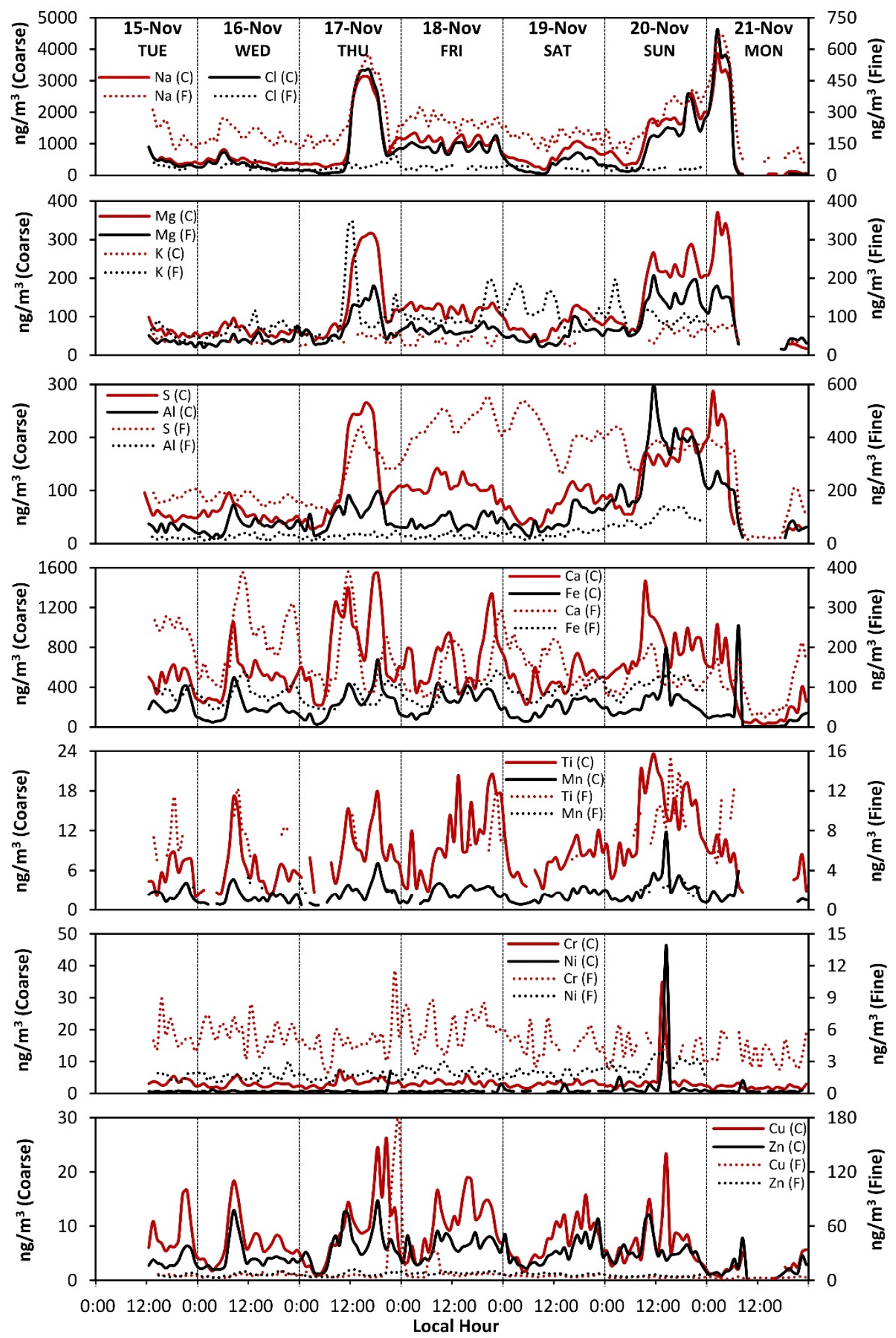

Fig. 4. Time series of analysed elements in fine $(\mathrm{F})$ and coarse $(\mathrm{C})$ fractions. Red lines represent elements in coarse fraction (right $\mathrm{Y}$-axis) and grey lines in fine fraction (left $\mathrm{Y}$-axis). Concentrations are in $\mathrm{ng} \mathrm{m}^{-3}$.

of $\mathrm{Cl}(\mathrm{F})$ was much lower, possibly because $\mathrm{Cl}$ is mainly distributed in the coarse fraction and chloride depletion increases with the decrease in particle size (Yao et al., 2003).

\section{SDE and Wet Scavenging}

As already mentioned a SDE occurred between $20^{\text {th }}$ and $21^{\text {st }}$ of November, followed by a precipitation episode resulting in scavenging of particles by wet deposition. As 
shown in Fig. 1, this event had a stronger effect on larger particles. Throughout the event two well-defined concentration peaks were registered, one at the beginning $\left(\sim 14: 00\right.$ on $\left.20^{\text {th }}\right)$ and the other at the end $\left(\sim 07: 00\right.$ on $\left.21^{\mathrm{st}}\right)$. The maximum impact of rainfall was around 08:00 on $21^{\text {st }}$.

Significant increases in the concentrations of many elements were observed during the SDE (Fig. 4). For instance, the increase in the $\mathrm{Fe}(\mathrm{C})$ concentration at around 07:00 coincided with the peak in the number concentration of coarse particles (Fig. 1). To quantify the impact of SDE on elemental concentrations, mean levels were calculated for event and non-event periods (Table 2). These values were obtained from daily averages. For this reason, the time interval between 07:00 on $19^{\text {th }}$ and $07: 00$ on $20^{\text {th }}$ was considered as a nonevent day, while the period from 07:00 on $20^{\text {th }}$ to $07: 00$ on $21^{\text {st }}$ was an event day. Table 2 also presents increase factors for each element.

As may be expected, the highest increase factors were obtained for coarse particles, confirming the greater impact of SDE on this fraction in the study area. Crustal elements showed significant increases in the coarse fraction. In contrast, only Al showed a substantial increment in the fine fraction, probably because other crustal elements have also a significant contribution from other sources. Increases in the levels of marine elements $(\mathrm{Na}, \mathrm{Mg}, \mathrm{Br}$ and $\mathrm{Cl})$ in the coarse fraction were higher than for the other elements. This is probably the result of the uptake of these species during the transport of Saharan air masses over the Mediterranean Sea. Anthropogenic elements (like V and Ni) emitted in the Mediterranean Basin and northern Africa (mainly from fuel oil combustion in industries and ships) could also be transported to the sampling site by Saharan dust plumes (Galindo et al., 2017, 2018). Notable increases for $\mathrm{Na}$ and $\mathrm{Mg}$ were also observed in the fine fraction.

The concentration of $\mathrm{S}$ in the coarse fraction significantly increased during the event most likely due to the formation of coarse $\mathrm{CaSO}_{4}$. In some previous studies performed in the study area (Nicolás et al., 2009b; Galindo et al., 2020), we have reported increases in the concentrations of fine sulphate and ammonium during Saharan events, pointing to the formation of fine $\left(\mathrm{NH}_{4}\right)_{2} \mathrm{SO}_{4}$ during these episodes. However, for the studied event, an increase in sulphur concentrations in the fine fraction was not observed. Therefore, the formation of fine calcium sulphate, as suggested by Cesari et al. (2016), did not occur (notice that fine calcium concentrations also did not increase during this particular event; Table 2). A plausible explanation is that there was not enough ammonia present to neutralize the extra amount of sulphuric acid generated during the event. Consequently, sulphuric acid was mostly neutralized by coarse $\mathrm{CaCO}_{3}$.

As can be seen in Fig. 4, during this event, maximum hourly concentrations of some elements can be twice ( $\mathrm{Na}, \mathrm{S}$, $\mathrm{Al}, \mathrm{Ca}$ and $\mathrm{Ti}$ ) or even three times $(\mathrm{Fe}$ and $\mathrm{Cl}$ ) higher than the average daily values shown in Table 2 .

Rainfall affected most of the elements in both the fine and coarse fractions, as can be seen in Fig. 4. In some cases, concentrations decreased so much that they even fell below detection limits [for example, $\mathrm{Ti}(\mathrm{C}), \mathrm{Ti}(\mathrm{F}), \mathrm{Mg}(\mathrm{C}), \mathrm{Mg}(\mathrm{F})$, $\mathrm{K}(\mathrm{C})$ or $\mathrm{K}(\mathrm{F})]$. On the other hand, the reduction in mass concentrations caused by precipitation was not uniform for both size fractions. In fact, elements in the coarse fraction were more affected by wet scavenging. Fig. 5 shows the decrease in elemental concentrations for $\mathrm{Na}, \mathrm{Ca}, \mathrm{Fe}$ and $\mathrm{S}$ during the precipitation event.

As can be seen in Figs. 5(a) and 5(d), during the episode, concentrations of $\mathrm{Na}(\mathrm{F}), \mathrm{Na}(\mathrm{C})$ and $\mathrm{S}(\mathrm{C})$ fell below detection limits. Regarding Ca (Fig. 5(b)), concentrations significantly decreased in both fractions; however, the decay factor (i.e., the ratio of calcium concentrations before and just after the precipitation event) was higher for the coarse fraction

Table 2. Elemental concentrations $\left(\mathrm{ng} \mathrm{m}^{-3}\right)$ calculated for SDE and non-event periods. Increase factors are also shown.

\begin{tabular}{|c|c|c|c|c|c|c|}
\hline & \multicolumn{2}{|c|}{ Coarse Fraction } & \multirow{2}{*}{$\begin{array}{l}\text { Increase Factor } \\
\text { (Coarse) }\end{array}$} & \multicolumn{2}{|c|}{ Fine Fraction } & \multirow{2}{*}{$\begin{array}{l}\text { Increase Factor } \\
\text { (Fine) }\end{array}$} \\
\hline & Non-SDE & SDE & & Non-SDE & SDE & \\
\hline $\mathrm{Na}$ & 619.8 & 1966.1 & 3.17 & 172.7 & 372.3 & 2.16 \\
\hline $\mathrm{Mg}$ & 81.8 & 225.4 & 2.75 & 33.6 & 61.4 & 1.83 \\
\hline $\mathrm{Al}$ & 60.7 & 160.5 & 2.64 & 49.7 & 94.8 & 1.91 \\
\hline $\mathrm{Si}$ & 274.7 & 513.4 & 1.87 & & & \\
\hline $\mathrm{P}$ & 19.8 & 21.8 & 1.10 & - & - & - \\
\hline S & 75.9 & 172.3 & 2.27 & 382.3 & 353.0 & 0.92 \\
\hline $\mathrm{Cl}$ & 336.4 & 1838.6 & 5.46 & 30.5 & 31.2 & 1.02 \\
\hline $\mathrm{K}$ & 55.7 & 142.0 & 2.55 & 103.0 & 86.8 & 0.84 \\
\hline $\mathrm{Ca}$ & 523.2 & 805.4 & 1.54 & 136.7 & 127.8 & 0.93 \\
\hline $\mathrm{V}$ & - & - & - & 6.3 & 9.4 & 1.48 \\
\hline $\mathrm{Ti}$ & 7.9 & 14.2 & 1.79 & 4.5 & 5.3 & 1.19 \\
\hline $\mathrm{Cr}$ & 3.0 & 4.8 & 1.60 & 4.4 & 4.5 & 1.00 \\
\hline Mn & 2.2 & 3.5 & 1.58 & 1.8 & 2.3 & 1.24 \\
\hline $\mathrm{Fe}$ & 198.0 & 271.8 & 1.37 & 92.3 & 100.5 & 1.09 \\
\hline $\mathrm{Ni}$ & 1.1 & 3.2 & 2.91 & 2.0 & 2.7 & 1.31 \\
\hline $\mathrm{Cu}$ & 7.6 & 5.9 & 0.78 & 4.4 & 3.0 & 0.70 \\
\hline $\mathrm{Zn}$ & 5.5 & 4.5 & 0.82 & 6.0 & 4.5 & 0.75 \\
\hline $\mathrm{Sr}$ & 1.6 & 3.4 & 2.06 & - & - & - \\
\hline $\mathrm{Br}$ & 0.8 & 2.0 & 2.52 & - & - & - \\
\hline
\end{tabular}


a)

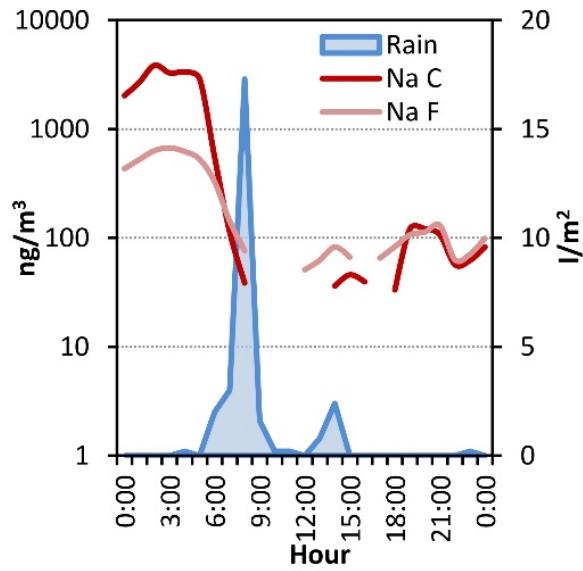

b)

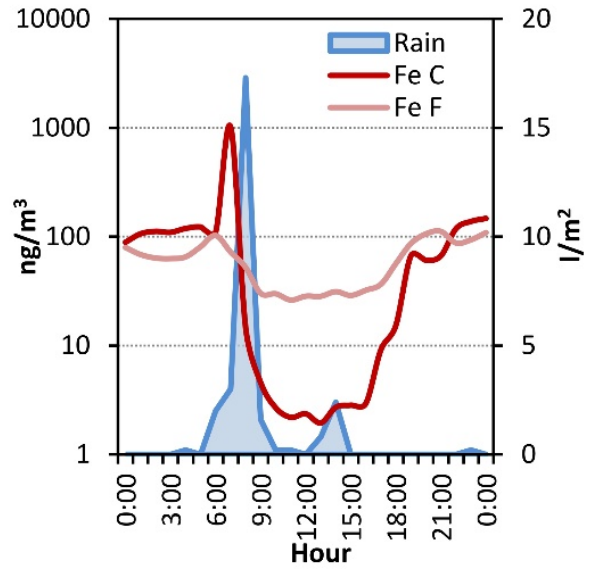

c)

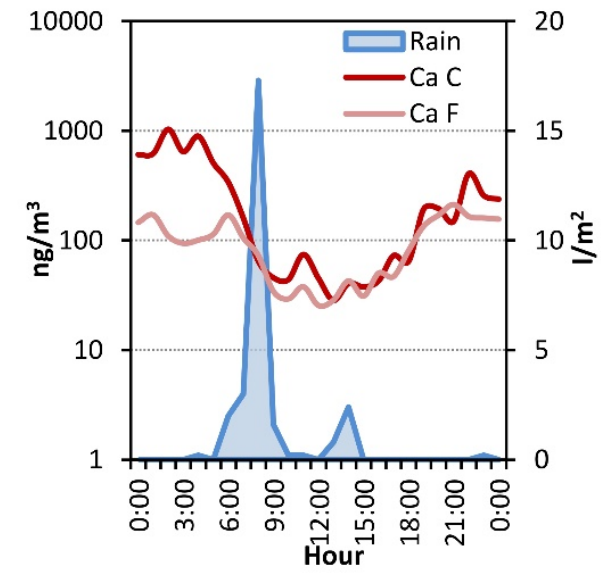

d)

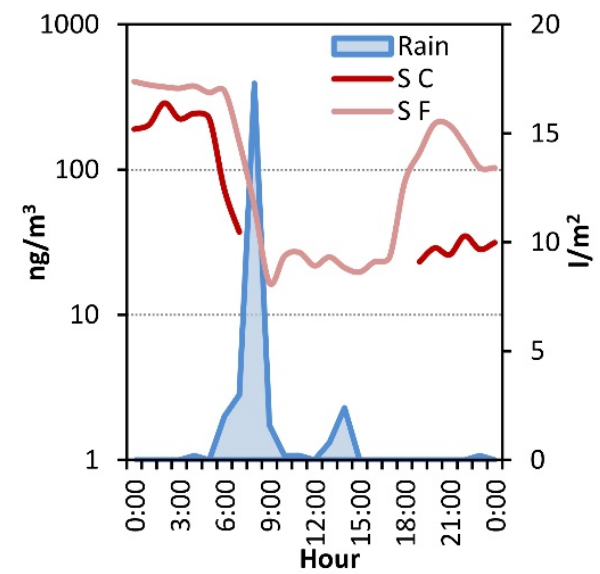

Fig. 5. Impact of the precipitation episode on the concentrations of: a) $\mathrm{Na}$, b) $\mathrm{Fe}$, c) Ca, d) S.

than for the fine fraction. A similar behaviour was observed for Fe (Fig. 5(c)). Table 3 shows decay factors for all the analysed elements in both fractions. These factors have been calculated using elemental hourly concentrations measured before (03:00-04:00) and after (11:00-12:00) the precipitation event. $<M D L$ indicates that concentrations during the episode fell below detection limits.

All the elements in the coarse fraction (with the exception of $\mathrm{Ni}$ and $\mathrm{Cr}$ ) were practically removed (concentrations < MDL) from the atmosphere during the event. The impact of rainfall on the fine fraction was significantly lower. In fact, elements like $\mathrm{Cu}$ and $\mathrm{Cl}$ did not show any decrease during the episode. This outcome highlights a greater removal efficiency by wet scavenging for coarse particles than for fine particles. Comparable results were found in Milan (Vecchi et al., 2009) where, in a rainy episode similar to the one studied here (rainfall of $25 \mathrm{~L} \mathrm{~m}^{-2}$ in one hour), decreases of $90 \%$ in the coarse fraction and only $25 \%$ in the range $0.5-2.5 \mu \mathrm{m}$ were registered. In the same way, wet scavenging of coarse particles stopped abruptly an extreme Saharan outbreak observed in Lecce (SE Italy) (Conte et al., 2020).

From the plots in Fig. 5 the time needed to reach pre-event concentrations can be estimated. Around 18:00-19:00, concentration values previous to the event were re-established or, at least, they were above the MDL for most of the analysed elements. Therefore, a recovery period of approximately 10-12 hours can be established.
Table 3. Decay factors for the analysed elements due to the precipitation event.

\begin{tabular}{lll}
\hline Element & Decay factor (Coarse) & Decay Factor (Fine) \\
\hline $\mathrm{Na}$ & $<\mathrm{MDL}$ & $<\mathrm{MDL}$ \\
$\mathrm{Mg}$ & $<\mathrm{MDL}$ & $<\mathrm{MDL}$ \\
$\mathrm{Al}$ & $<\mathrm{MDL}$ & 7.8 \\
$\mathrm{~S}$ & $<\mathrm{MDL}$ & 13.5 \\
$\mathrm{Cl}$ & $<\mathrm{MDL}$ & 0.8 \\
$\mathrm{~K}$ & $<\mathrm{MDL}$ & $<\mathrm{MDL}$ \\
$\mathrm{Ca}$ & 8.7 & 2.5 \\
$\mathrm{Ti}$ & $<\mathrm{MDL}$ & $<\mathrm{MDL}$ \\
$\mathrm{Cr}$ & 1.7 & 1.3 \\
$\mathrm{Mn}$ & $<\mathrm{MDL}$ & $<\mathrm{MDL}$ \\
$\mathrm{Fe}$ & 50.1 & 2.4 \\
$\mathrm{Ni}$ & 1.1 & 1.5 \\
$\mathrm{Cu}$ & $<\mathrm{MDL}$ & 0.5 \\
$\mathrm{Zn}$ & $<\mathrm{MDL}$ & 2.0 \\
\hline
\end{tabular}

\section{CONCLUSIONS}

This study investigated changes in the PM elemental composition in response to daily traffic cycles and two shortterm meteorological events. The high temporal resolution of the data set enabled us to identify the elements typically associated with non-exhaust vehicle emissions $(\mathrm{Cu}, \mathrm{Zn}, \mathrm{Mn}$, $\mathrm{Al}, \mathrm{Ca}, \mathrm{Ti}$ and $\mathrm{Fe}$ in the coarse fraction) as the best tracers 
of traffic variability, with the coefficients of determination between these elemental concentrations and the traffic volume exceeding 0.5 on working days.

Likewise, elements in the coarse fraction were found to be good indicators of certain non-anthropic events. The concentrations of marine elements $(\mathrm{Na}, \mathrm{Mg}$ and $\mathrm{Cl}$ ) not only increased under sea breeze conditions, but also under the Saharan dust episode. In fact, it is noteworthy that increase factors for crustal elements (for instance, $\mathrm{Ti}, \mathrm{Fe}, \mathrm{Si}, \mathrm{Al}$ or $\mathrm{Sr}$ in the coarse fraction) during this event were lower than those obtained for marine elements.

Wet deposition removed coarse particles more efficiently than fine particles from the atmosphere, with the concentrations of most of the elements in the coarse fraction falling below detection limits during a brief and intense rainfall event. Following this precipitation, approximately 10-12 hours were required for these concentrations to revert to their pre-event levels.

\section{ACKNOWLEDGEMENTS}

This work was supported by the Valencian Regional Government under the GV/2017/199 and AICO/2018/085 research projects.

\section{SUPPLEMENTARY MATERIAL}

Supplementary data associated with this article can be found in the online version at http://www.aaqr.org.

\section{REFERENCES}

Alves, C.A., Evtygina, M., Vicente, A.M.P., Vicente, E.D., Nunes, T.V., Silva, P.M.A., Duarte, M.A.C., Pio, C.A., Amato, F. and Querol, X. (2018). Chemical profiling of $\mathrm{PM}_{10}$ from urban road dust. Sci. Total Environ. 634: 41-51.

Amato, F., Schaap, M., Denier van der Gon, H.A.C., Pandolfi, M., Alastuey, A., Keuken, M. and Querol, X. (2012). Effect of rain events on the mobility of road dust load in two Dutch and Spanish roads. Atmos. Environ. 62: 352-358.

Amato, F., Alastuey, A., Karanasiou, A., Lucarelli, F., Nava, S., Calzolai, G., Severi, M., Becagli, S., Gianelle, V.L., Colombi, C., Alves, C., Custodio, D., Nunes, T., Cerqueira, M., Pio, C., Eleftheriadis, K., Diapouli, E., Reche, C., Minguillón, M.C., Manousakas, M.I., Maggos, T., Vratolis, S., Harrison, R.M. and Querol, X. (2016). AIRUSE-LIFE+: A harmonized PM speciation and source apportionment in five southern European cities. Atmos. Chem. Phys. 16: 3289-3309.

Andronache, C. (2003). Estimated variability of belowcloud removal by rainfall for observed aerosol size distributions. Atmos. Chem. Phys. 3: 131-143.

Bardouki, H., Liakakou, H., Economou, C., Sciare, J., Smolík, J., Zdímal, V., Eleftheriadis, K., Lazaridis, M., Dye, C. and Mihalopoulos, N. (2003). Chemical composition of size resolved atmospheric aerosols in the eastern Mediterranean during summer and winter. Atmos. Environ. 37: 195-208.
Calzolai, G., Chiari, M., Lucarelli, L., Nava, S. and Portarena, S. (2010). Proton induced $\gamma$-ray emission yields for the analysis of light elements in aerosol samples in an external beam set-up. Nucl. Instrum. Methods Phys. Res., Sect. B 268: 1540-1545.

Calzolai, G., Lucarelli, F., Chiari, M., Nava, S., Giannoni, M., Carraresi, L., Prati, P. and Vecchi, V. (2015). Improvements in PIXE analysis of hourly particulate matter samples. Nucl. Instrum. Methods Phys. Res., Sect. $B$ 363: 99-104.

Campbell, J.L., Boyd, N.I., Grassi, N., Bonnick, P. and Maxwell, J.A. (2010). The Guelph PIXE software package IV. Nucl. Instrum. Methods Phys. Res., Sect. B 268: 3356-3363.

Cesari, D., Donateo, A., Conte, M., Merico, E., Giangreco, A. and Contino, D. (2016). An intercomparison of $\mathrm{PM}_{2.5}$ at urban at urban background sites: Chemical characterization and source apportionment. Atmos. Res. 174-175: 106-119.

Chiari, M., Carmine, P.D., Orellana, I.G., Lucarelli, F., Nava, S. and Paperetti, L. (2006). Hourly elemental composition and source identification of fine and coarse $\mathrm{PM}_{10}$ in an Italian urban area stressed by many industrial activities. Nucl. Instrum. Methods Phys. Res., Sect. B 249: 584-587.

Conte, M., Merico, E., Cesari, D., Dinoi, A., Grasso, F.M., Donateo, A., Guascito, M.R. and Contini, D. (2020). Long-term characterisation of African dust advection in south-eastern Italy: Influence on fine and coarse particle concentrations, size distributions, and carbon content. Atmos. Res. 233: 104690.

Contini, D., Cesari, D., Genga, A., Siciliano, M., Ielpo, P., Guascito, M.R. and Conte, M. (2014). Source apportionment of size-segregated atmospheric particles based on the major water-soluble components in Lecce (Italy). Sci. Total Environ. 472: 248-261.

Crilley, R., Lucarelli, F., Bloss, W., Harrison, R.M., Beddows, D.C., Calzolai, G., Nava, S., Valli, G., Bernardoni, V. and Vecchi, R. (2016). Source apportionment of fine and coarse particles at a roadside and urban background site in London site during the 2012 summer ClearfLo campaign. Environ. Pollut. 220: 766-778.

Cuspilici, A., Monforte, P. and Ragusa, M.A. (2017). Study of Saharan dust influence on $\mathrm{PM}_{10}$ measures in Sicily from 2013 to 2015. Ecol. Indic. 76: 297-303.

Dall'Osto, M., Querol, X., Amato, F., Karanasiou, A., Lucarelli, F., Nava, S., Calzolai, G. and Chiari, M. (2013). Hourly elemental concentrations in $\mathrm{PM}_{2.5}$ aerosols sampled simultaneously at urban background and road site during SAPUSS-diurnal variations and PMF receptor modelling. Atmos. Chem. Phys. 13: 4375-4392.

Escudero, M., Querol, X., Ávila, A. and Cuevas, E. (2007). Origin of exceedances of the European daily PM limit value in regional background areas of Spain. Atmos. Environ. 41: 730-744.

Feng, X. and Wang, S. (2012). Influence of different weather events on concentrations of particulate matter with different sizes in Lanzhou, China. J. Environ. Sci. 24: 665-674. 
Galindo, N. and Yubero, E. (2017). Day-night variability of water-soluble ions in $\mathrm{PM}_{10}$ samples collected at a traffic site in southeastern Spain. Environ. Sci. Pollut. Res. 24: 805-812.

Galindo, N., Yubero, E., Nicolás, J.F., Crespo, J., Varea, M. and Gil-Moltó, J. (2017). Regional and long-range transport of aerosols at Mt. Aitana, Southern Spain. Sci. Total Environ. 584-585: 723-730.

Galindo, N., Yubero, E., Nicolás, J.F., Varea, M. and Crespo, J. (2018). Characterization of metals in $\mathrm{PM}_{1}$ and $\mathrm{PM}_{10}$ and health risk evaluation at an urban site in the western Mediterranean. Chemosphere 201: 243-250.

Galindo, N., Yubero, E., Clemente, A., Nicolás, J.F., Varea, M. and Crespo, J. (2020). PM events and changes in the chemical composition of urban aerosol: A case study in the western Mediterranean. Chemosphere 244: 125520.

Handler, M., Puls, C., Zbiral, J., Marr, I., Puxbaum, H. and Limbeck, A. (2008). Size and composition of particulate emissions from motor vehicles in the KaisermühlenTunnel, Vienna. Atmos. Environ. 42: 2173-2186.

Lawrence, S., Sokhi, R., Ravindra, H., Mao, H., Prain, H.D. and Bull, I.D. (2013). Source apportionment of traffic emissions of particulate matter using tunnel measurements. Atmos. Environ. 77: 548-557.

Loosmore, G.A. and Cederwall, R.T. (2004). Precipitation scavenging of atmospheric aerosols for emergency response applications: Testing an updated model with new real-time data. Atmos. Environ. 38: 993-1003.

Lucarelli, F., Calzolai, G., Chairi, M., Giannoni, M., Mocho, D., Nava, S. and Carresi, L. (2014). The upgraded external-beam PIXE/PIGE set up at LABEC for very fast measurements on aerosol samples. Nucl. Instrum. Methods Phys. Res., Sect. B 318: 55-59.

Lucarelli, F., Mandò, P.A., Nava, S., Valerio, M., Prati, P. and Zucchiatti, A. (2000). Elemental composition of urban aerosol collected in Florence, Italy. Environ. Monit. Assess. 65: 165-173.

Lucarelli, F., Calzolai, G., Chairi, M., Nava, S. and Carraresi, L. (2018). Study of atmospheric aerosols by IBA techniques: The LABEC experience. Nucl. Instrum. Methods Phys. Res., Sect. B 417: 121-127.

Malaguti, A., Mircea, M., La Torretta, T.M., Telloli, C., Petralia, E., Stracquadanio, M. and Berico, M. (2015). Chemical composition of fine and coarse aerosol particles in the Central Mediterranean area during dust and nondust conditions. Aerosol Air Qual. Res. 15: 410-425.

Minguillón, M.C., Cirach, M., Hoek, G., Brunekreef, B., Tsai, M., de Hoogh, K., Jedynska, A., Kooter, I.M., Nieuwenhuijsen, M. and Querol, X. (2014). Spatial variability of trace elements and sources for improved exposure assessment in Barcelona. Atmos. Environ. 89: 268-281.

Moreno, T., Karanasiou, A., Amato, F., Lucarelli, F., Nava, S., Calzolai, G., Chiari, M., Coz, E., Artiñano, B., Lumbreras, J., Borge, R., Boldo, E., Linares, C., Alastuey, A., Querol,
X. and Gibbons, W. (2013). Daily and hourly sourcing of metallic and mineral dust in urban air contamined by traffic and coal-burning emissions. Atmos. Environ. 68: $33-44$.

Nava, S., Becagli, S., Calzolai, G., Chiari, M., Lucarelli, F., Prati, P., Travesi, R., Udisti, R., Valli, G. and Vecchi, R. (2012). Saharan dust impact in central Italy: An overview on three years element data records. Atmos. Environ. 60: 444-452.

Nicolás, J.F., Yubero, E., Galindo, N., Giménez, J., Castañer, R., Carratalá, A., Crespo, J. and Pastor, C. (2009a). Characterization of events by aerosol mass size distributions. J. Environ. Monit. 11: 394-399.

Nicolás, J.F., Galindo, N., Yubero, E., Pastor, C., Esclapez, R. and Crespo, J. (2009b). Aerosol inorganic ions in a semiarid region on the southeastern Spanish Mediterranean coast. Water Air Soil Pollut. 201: 149-159.

Nicolás, J.F., Chiari, M., Crespo, J., Galindo, N., Lucarelli, F., Nava, S. and Yubero, E. (2011). Assessment of potential source regions of $\mathrm{PM}_{2.5}$ components at a southwestern Mediterranean site. Tellus B 63: 96-106.

Nicolás, J.F., Crespo, J., Yubero, E., Soler, R., Carratalá, A. and Mantilla, E. (2014). Impacts on particles and ozone by transport processes recorded at urban and high-altitude monitoring stations. Sci. Total Environ. 466-467: 439446.

Pant, P. and Harrison, R.M. (2013). Estimation of the contribution of road traffic emissions to particulate matter concentrations from field measurements: A review. Atmos. Environ. 77: 78-97.

Pey, J., Querol, X. and Alastuey, A. (2009). Variations of levels and composition of $\mathrm{PM}_{10}$ and $\mathrm{PM}_{2.5}$ at an insular site in the Western Mediterranean. Atmos. Res. 94: 285299.

PIXE International Corporation, Website: http://pixeintl. com/Streaker.asp.

Thorpe, A. and Harrison, R.M. (2008). Sources and properties of non-exhaust particulate matter from road traffic: A review. Sci. Total Environ. 400: 270-282.

Vecchi, R., Bernardoni, V., Fermo, P., Lucarelli, F., Mazzei, F., Nava, S., Prati, P., Piazzalunga, A. and Valli, G. (2009). 4-hours resolution data to study $\mathrm{PM}_{10}$ in a "hot spot" area in Europe. Environ. Monitor. Assess. 154: 283-300.

Yao. X., Fang, M. and Chan, C.K. (2003). The size dependence of chloride depletion in fine and coarse seasalt particles. Atmos. Environ. 37: 743-751.

Yubero, E., Galindo, N., Nicolás, J.F., Crespo, J., Calzolai, G. and Lucarelli, F. (2015). Temporal variations of PM major components in an urban street canyon. Environ. Sci. Pollut. Res. 22: 13328-13335.

Received for review, September 5, 2019 Revised, February 3, 2020 Accepted, February 23, 2020 